Original Research

\title{
Cardiovascular Risk Estimation in Patients with Hypertension: A Cross- Sectional Study
}

\section{Nyayu Nina Putri Calisanie, Santi Susanti, and Linlin Lindayani}

Sekolah Tinggi Ilmu Keperawatan PPNI West Java, Bandung, West Java, Indonesia

\section{ABSTRACT}

Introduction: Cardiovascular disease is a disease caused by the misfunctioning of the heart and blood vessels. Atherosclerosis is the main cause of cardiovascular disease. Prevention and control of cardiovascular disease can be done with early detection through screening activities. Framingham Risk Score using Body Mass Index (FRS BMI) risk assessment is very useful and easy, which is used without using lipid indicator. This study aims to estimate the risk of cardiovascular disease on patients with hypertension with Framingham Risk Score BMI.

Methods: The study used a descriptive method with cross-sectional design. The samples in this study were 130 respondents who were selected using consecutive sampling and retrieval technique by using FRS BMI application questionnaire.

Results: There were $11.5 \%$ respondents in low risk of CVD, 22.7\% respondents at moderate risk and $60.8 \%$ respondents in higher category of cardiovascular disease 10 years later.

Conclusion: Majority of patients with hypertension showed a high risk of CVD for the next 10 years. Patients' sex and age also play an important role to increase the risk, whereby men show a higher risk of CVD for the next ten years. The hospital management and health worker should pay more attention and educate the patient about the prevention of heart disease for the next 10 years, especially for those with high risk of CVD based on FRS BMI measurement.

\section{ARTICLE HISTORY}

Received: November 25, 2019

Accepted: June 24, 2020

KEYWORDS

cardiovascular disease; framingham risk score BMI; hypertension

\section{CONTACT}

Linlin Lindayani $\triangle$ linlinlindayani@gmail.com $\ggg$ Sekolah Tinggi Ilmu Keperawatan PPNI Jawa Barat, Jawa Barat, Indonesia

Cite this as: Calisanie, N. N. P., Susanti, S., \& Lindayani, L. (2020). Cardiovascular Risk Estimation in Patients with Hypertension: A Cross- Sectional Study. Jurnal Ners, 15(1). 98-104. doi:http://dx.doi.org/10.20473/jn.v15i1.16262

\section{INTRODUCTION}

Hypertension has become a global disease, both in developed and developing countries. Hypertension is also referred to as a "silent killer" because, in some cases, it can appear without symptoms but suddenly result in death (Nuraini, 2015). The development of hypertension is gradual so it is often not realized by the sufferers. Hypertension is defined as an increase in systolic blood pressure of more than $140 \mathrm{mmHg}$ and diastolic blood pressure of more than $90 \mathrm{mmHg}$ at two measurements between a five minute interval in a good condition (Kemenkes, 2014). Hypertension which lasts for a long time (persistent) can cause damage to the kidneys, heart and brain (West Java Health Office, 2016).

According to data from Dhungana et al. (2018), the prevalence of hypertension worldwide is around 972 million or $26.4 \%$ of people. The number is likely to increase to $29.2 \%$ in 2025. From 972 million cases of hypertension, 333 million occurred in developed countries and the remaining 639 million were in developing countries, including Indonesia (Yonata, Satria, \& Pratama, 2016). Meanwhile, based on the results of the 2018 Baseline Health Research report, hypertension increased from 2013 as much as $25.8 \%$ to $34.1 \%$ from the results of measurements on the population aged over 18 years (Badan Penelitian \& Pengembangan Kesehatan, 2018). By 2016 in West Java 790,382 cases of hypertension $(2.46 \%$ of the population $\geq 18$ years) were found with a total of $8,029,245$ cases examined in 26 districts or cities (West Java Health Office, 2016).

According to Whelton et al. (2018), the prevalence of hypertension in stage 1 showed more 
men with hypertension than women, while, in stage 2, it affects more women. Women more than 55 years are more at risk of suffering hypertension than men. Complications of hypertension cause around 9.4 million deaths worldwide each year. Hypertension causes at least $45 \%$ of deaths due to heart disease and $51 \%$ of deaths due to stroke (Kemenkes, 2014). Increasing age and increasing numbers of hypertensive patients raise major problems associated to cardiovascular disease.

Cardiovascular disease is caused by impaired heart and blood vessel function WHO (2019). Globally, among non-infectious diseases, the number one cause of death annually is cardiovascular disease (Kemenkes, 2014). According to the WHO (2019), around 17.5 million people worldwide die from cardiovascular disease and the disease accounts for $31 \%$ of deaths worldwide. Deaths caused by cardiovascular disease, especially coronary heart disease and stroke, are expected to keep increasing, reaching 23.3 million in 2030 (Kemenkes, 2014).

Hypertension is a factor that plays a role in the pathogenesis process of cardiovascular disease through atherosclerosis process. According to Budiman, Sihombing, and Pradina, (2015), the process of atherosclerosis in artery walls will facilitate the formation of blood clots and weaken the blood vessels of patients. So that the effects that occur in the heart arteries continuously cause damage to the arterial blood system leading to a hardening or stiffness process.

According to Frostegård (2013), atherosclerosis is a major cause of cardiovascular disease. Atherosclerosis is a chronic inflammatory condition in blood vessels that can cause plaque in artery walls (AHA, 2019). Cardiovascular disease or atherosclerosis cardiovascular disease includes cardiovascular disease coronary heart disease, myocardial infarction, and stroke (Lloyd-Jones et al., 2019). Plaque can be formed from cholesterol, fatty substances, calcium and fibrin. When plaque builds up, it can narrow the channels in the arteries, partially or completely, in the heart arteries (AHA, 2019).

Efforts to prevent and control cardiovascular disease can be done with early detection through screening activities, so that the possibility complications risk, such as coronary heart disease, myocardial infarction, and stroke, can be prevented. Health screening for disease prevention has long been used as the most important healthcare strategy to provide patients with early diagnosis and treatment, improvement in quality of life, and preventing premature death (Bell et al., 2017). Currently, there are many global researches developed on how much a person is affected by cardiovascular disease, one of which uses Framingham Risk Score using Body Mass Index (FRS BMI)application. According to Emor,
Panda, and Pangemanan (2017), this can be done as primary prevention in patients who already have risk factors, but have never experienced cardiovascular disease. The result of FRS BMI is a calculation of the risk of atherosclerotic cardiovascular disease in the next 10 years (Lloyd-Jones et al., 2019). This FRS BMI application measures the risk of cardiovascular disease with indicators of age, sex, systolic blood pressures, hypertension treatment, smoking status, diabetes mellitus, and BMI. Risk assessment using FRS BMI is very useful and practical to use without using the measured lipid indicators, making it easier to detect early in controlling cardiovascular disease risk factors, among which are systolic blood pressure, smoking habits and body mass index.

The results of Emor et al's (2017) study regarding the prediction of the risk of atherosclerotic cardiovascular disease in patients seeking treatment at internal medicine clinics in RSUP Prof. Dr. RD Kandaou Manado shows the results of the number of patients $(n=100)$ with the predicted risk level of the next ten years for atherosclerotic cardiovascular disease; $(n=42)$ patients have a low risk level of $42 \%$, moderate $27 \%$ and high $31 \%$ based on Framinghan Risk Score. This study also states that patients with systolic blood pressure $\geq 160 \mathrm{mmHg}$ were not found with low and moderate risk, but high risk. Hassan et al. (2018) conducted a research on the prediction of atherosclerotic cardiovascular disease in the population of Pakistan, and found that smoking history, diabetes type 2 and hypertension are the main potential risk factors underlying ASCVD (Atherosclerotic Cardiovascular Disease) in individuals in Pakistan. No study has been conducted in Indonesia to explore the risk of cardiovascular disease in hypertensive patients using FRS BMI, which is considered as a useful tool. The purpose of this study was to estimate cardiovascular disease in hypertensive patients in Indonesia.

\section{MATERIALS AND METHODS}

The research design used in this study was quantitative descriptive, with cross-sectional approach. The study population was hypertension patients in hospitals in West Java. The sample size in this study was determined using G-power software version 3. 1. 9.2 (Cohen, 1992) to determine the estimated frequency of cardiovascular risk in hypertensive patients using the exact test and statistical test, that are the proportion difference from constant (binominal test, one sample case) assuming $\alpha=0.05$, medium effect size $=0.15$, power level $=0.95$ and constant proportion $=0.5$; the maximum total sample recruited is 119 people. To avoid data error, the number of respondents was 
added by $10 \%$ for researcher errors and for sample errors measured. Therefore, the total sample recruited in this study was 130 people.

Table 1. Estimated CVD Risk for Hypertensive Patients $(\mathrm{n}=130)$

\begin{tabular}{lc}
\hline \multicolumn{1}{c}{ Risk Estimation } & n (\%) \\
\hline Low & $15(11.5)$ \\
Medium & $36(22.7)$ \\
High & $79(60.8)$ \\
\hline
\end{tabular}

Table 2. Characteristics of Respondents ( $\mathrm{n}=130)$

\begin{tabular}{lr}
\hline \multicolumn{1}{c}{ Variable } & n (\%) \\
\hline Gender & $38(29.2)$ \\
Male & $92(70.8)$ \\
Female & \\
Age & $61.3 \pm 8.74$ \\
mean \pm SD & $40 \pm 74$ \\
min \pm max & $8(6.2)$ \\
$36-45$ years old & $24(18.5)$ \\
46-55 years old & $46(35.4)$ \\
56-65 years old & $52(40.0)$ \\
$\quad>65$ years old & $10(7.7)$ \\
Occupation & $4(3.1)$ \\
Unemployed & $8(6.2)$ \\
Labor & $5(3.8)$ \\
Trader & \\
Private sector & \\
$\quad$ employee) & $30(23.1)$ \\
Civil Servant & $46(35.4)$ \\
House Wife & $27(20.8)$ \\
Retired & \\
Education & $1(0.8)$ \\
Uneducated & $26(20.0)$ \\
Elementary School & $29(23.3)$ \\
Junior High School & $55(42.3)$ \\
Senior High School & $19(14.6)$ \\
College &
\end{tabular}

The inclusion criteria of this study were hypertension patients who have hypertension systolic, documented height and body weight (to measure the body mass index), and aged above 35 years old according to the recommendation from using Framingham Risk Score BMI (for aged above 25 years old), and have been diagnosed with hypertension for more than one year. The exclusion criteria were patient already diagnosed with cardiovascular disease and other medication, chronic kidney disease, tuberculosis, cancer-related disease, and pregnant women. Consecutive sampling technique was used to take all respondents that met the inclusion criteria until the sample size was fulfilled.

The instrument used for this research was the application of FRS BMI (Framingham Risk Score using Body Mass Index) developed by Agostino et al. (2008) in collaboration with Boston University and the National Herat, Lung, and Blood Institute. Indicators assessed gender, age, systolic blood pressure, treatment of hypertension, current smoking, diabetes mellitus status and BMI. Cardiovascular disease outcomes include stroke, chronic heart disease, myocardial infarction, and peripheral arterial disease and heart failure. Risk assessment can be calculated using the following formula (Agostino et al., 2008). Reliabilities of the original Framingham function and of the best Cox model fit with the study data were similar in men (area under the receiver operator characteristic curve 0.68 and 0.69 , respectively, $\mathrm{p}=0.273$ ), whereas the best Cox model fitted better in women (0.73 and 0.81 , respectively, $\mathrm{p}=0.001)$ (Marrugat et al., 2007).

$$
\hat{p}=1-S_{0}(t)^{\exp }\left(\sum_{i}^{p}=1 \beta_{i} x_{i}-\sum_{i}^{p}=1 \beta i \bar{X} i\right)
$$

Note: Where $\mathrm{S} 0(\mathrm{t})$ is the baseline survival at follow-up time $t(t=10$ years; see Table 3.1$), \beta i$ is estimated regression coefficient (log hazard ratio; see Table 3.1), $\mathrm{Xi}$ is log-transformed value of risk factors, $\mathrm{X} \mathrm{i}$ is the corresponding mean, and shows the amount of risk factors. The 10-year CVD risk can be calculated as follows: the risk for women 1-0.95012exp ( $\Sigma ß X$ 26.1931). The risk for men 1-0.88936exp ( $\Sigma ß X$ 23.9802) (Agostino et al., 2008).

Ethical permission was conducted from the affiliated university (III/12/KEPK/STIKEP/JABAR/2019). In the implementation phase of the research for data collection, respondents used the application questionnaire. Selection of respondents was by means of patients who came that day, but researchers first looked at the criteria. Researchers looked at hypertensive patients from the patient's medical record to see that the respondents were indeed hypertensive patients. After that, the names of hypertensive patients were noted. After the respondent was summoned to the blood pressure measurement room by a nurse in the internal medicine clinic to be checked for blood pressure, weight and height, the researcher introduced themselves and provided a simple explanation of the purpose and objectives of this study. Questionnaires and informed consent were read by researchers to respondents. Respondents just answered questions from the researchers, then the researchers calculated the patient's BMI and FRS BMI score. Blood pressure, body weight, and TB data were obtained from the patient's medical record. For the stage of hypertension, this was seen from the doctor's diagnosis in the medical record.

\section{RESULTS}

Table 1 shows that more than half of respondents (60.8\%) have a high-risk category for the CVD in the next ten years particularly among hypertensive patients. On the other hand, a small proportion of respondents $(11.5 \%)$ have a low category. Table 2 shows that the majority of respondents $(70.8 \%)$ were female with an average age of 61.3 years (SD 8.74). Less than half of respondents $(35.4 \%)$ work as housewives with last education for less than half of respondents (42.3\%) was high school.

Table 3 shows that the average SBP stage is hypertension $142.20 \mathrm{mmHg}$. Hypertension patients without smoking habit have a greater percentage 
than those who smoke $(80.0 \%)$. As regard diabetes status, more than half of respondents (66.9\%) did not suffer from diabetes mellitus and the average BMI in hypertensive patients was 25.13 (SD 13.18). Comorbidity in hypertensive patients showed that more than half of the respondents $(63.8 \%)$ did not have concomitant diseases. The duration of HTN treatment and length of HTN suffered was an average of 6.21 years.

Table 4 shows the majority of respondents $(94.7 \%)$ were men at high risk of CVD in the next 10 years with a $p$ value of 0.000 . The age of hypertensive patients at high risk of CVD in the next 10 years was less than half of respondents (46.8\%) with age> 65 years. Then, for the stage of hypertension, most respondents $(84.2 \%)$ had a high risk of CVD in the next 10 years with a $p$ value of 0.001 . More than half of the respondents (68.4\%) were obese BMIs with a high risk of CVD in the next 10 years. The length of HTN and HTN treatment duration was more than half of respondents $(64.7 \%)$ or $>10$ years of high-risk CVD in the next 10 years with p value 0.180 .

\section{DISCUSSION}

The data show that more than half of respondents $(60.8 \%)$ were in high risk category in hypertensive patients to have CVD in the next 10 years. The results of this study are in line with the study of Sa'adeh et al. (2018), who stated that hypertensive patients with high knowledge scores and high attitude scores are significantly associated with high practice scores on the prevention of chronic kidney disease (CKD). Chronic kidney disease is a serious disease, but can be prevented with a three-level strategy, including education, modifying risk factors and screening.

This research shows that the high risk of CVD in hypertensive patients is influenced by high blood pressure. Increased blood pressure is a heavy burden on the heart, causing hypertrophy in the left ventricle or myocardial infarction. High and persistent blood pressure will cause direct trauma to the walls of the coronary arteries, making it easier for coronary atherosclerosis $\mathrm{t}$ occur. This causes angina pectoris (Anwar, 2004). High blood pressure continuously causes damage to the arterial system of the arteries, with the artery slowly also affected by increased cholesterol levels in the blood; this process constricts the lumen in the blood vessels so that blood flow becomes obstructed.

This study shows the results that the majority of respondents (94.7\%) of high-risk CVD in the next 10 years were men more than women. This is supported by Marso et al. (2016) who stated that the risk of CVD is greater in men than in women. Women are somewhat more resistant to this disease until the age after menopause and then become as vulnerable as men; this is because men do not have protective hormones like women, called the hormone estrogen, which functions as protection of the heart until before menopause.
Table 3. Clinical Information of Respondents $\underline{(n=130)}$

\begin{tabular}{lr}
\multicolumn{1}{c}{ Variable } & \multicolumn{1}{c}{ n (\%) } \\
\hline Hypertensive Stage (SBP) & \\
Mean \pm SD & $142.20 \pm 13.18$ \\
Min \pm Max & \\
Currently smoking status & $26(20.0)$ \\
Yes & $104(80.0)$ \\
No & \\
Diabetes Mellitus & $43(33.1)$ \\
Yes & $87(66.9)$ \\
No & \\
BMI & $25.13 \pm 4.13$ \\
mean \pm SD & $16.70 \pm 38.70$ \\
Min \pm max & \\
Comorbidity & $83(63.8)$ \\
No comorbidity & $3(2.3)$ \\
CKD & $43(33.1)$ \\
DM & $1(0.8)$ \\
TB & \\
Length of treatment & $6.21 \pm 6.91$ \\
Mean \pm SD & $1 \pm 49$ \\
Min \pm max & \\
Length of hypertension & \\
Mean \pm SD & $1 \pm 49$ \\
Min \pm max & \\
\hline
\end{tabular}

However, this study not only describes the sex, but, in terms of age, it depicted that as regard the age of hypertensive patients less than half the respondents were $>65$ years of high-risk CVD in the next 10 years. This is supported by Marleni and Alhabib (2017) at Siti Khadijah Hospital in Palembang who found that cardiovascular disease sufferers are more common in the age group $>45$ years. According to research conducted by Endah, Patriyani, and Purwanto (2016) 75\% of CHD occurred at the age of> 40 years. The American Heart Association (AHA) explains that age is an irreversible risk factor and the majority of people die from coronary heart disease aged 65 years or more (Arnett et al., 2019). Age is a risk factor for coronary heart disease where increasing age will increase the risk of coronary heart disease, the older the age the greater the emergence of plaque that sticks to the walls of blood vessels and causes disruption of blood flow through it.

Age factor has been shown to be related to death from coronary heart disease. Signs and symptoms of coronary heart disease are often found in older individuals (Ghani et al., 2016). Based on the results of this study and supported by theory and previous research, the researchers argue that coronary heart disease currently occurs considerably in old age, where the physiological physiology of the human body has decreased. That is because there are other trigger factors, especially in terms of lifestyle.

For stage of hypertension or SBP most of the respondents (84.2\%) have a high risk of CVD in the next 10 years. Other studies also reinforce that respondents with high risk of hypertension experience CHD 10.09 times compared with those 
Table 4. Frequency Distribution Based on Demographic Characteristics Differences of Hypertensive Patients at the Hospital Polyclinic in West Java $(\mathrm{N}=130)$

\begin{tabular}{|c|c|c|c|c|c|}
\hline \multirow[b]{2}{*}{ Variable } & \multicolumn{5}{|c|}{ Estimated CVD risk for the next 10 -years } \\
\hline & n (\%) & $\begin{array}{l}\text { Low } \\
\text { n (\%) }\end{array}$ & $\begin{array}{c}\text { Medium } \\
\text { n (\%) }\end{array}$ & $\begin{array}{l}\text { High } \\
\text { n (\%) }\end{array}$ & p value \\
\hline \multicolumn{6}{|l|}{ Sex } \\
\hline Male & $38(29.2)$ & 0 & $2(5.3)$ & $36(94.7)$ & 0.000 \\
\hline Female & $92(70.8)$ & $15(16.3)$ & $34(37.0)$ & $43(46.7)$ & \\
\hline \multicolumn{6}{|l|}{ Age } \\
\hline 36-45 Years Old & $8(6.2)$ & $6(40.0)$ & $2(5.6)$ & 0 & 0.000 \\
\hline 46-55 Years Old & $24(18.5)$ & $7(46.7)$ & $5(13.9)$ & $12(15.2)$ & \\
\hline 56-65 Years Old & $46(35.4)$ & $1(6.7)$ & $15(41.7)$ & $30(38.0)$ & \\
\hline$>65$ Years Old & $52(40.0)$ & $1(6.7)$ & $14(38.9)$ & $37(46.8)$ & \\
\hline \multicolumn{6}{|l|}{ Blood pressure } \\
\hline$<142,2$ & $92(70.8)$ & $15(16.3)$ & $30(32.6)$ & $47(51.1)$ & 0.001 \\
\hline$>142,2$ & $38(29.2)$ & 0 & $6(15.8)$ & $32(84.2)$ & \\
\hline \multicolumn{6}{|l|}{ Body Mass Index (BMI) } \\
\hline Underweight & $3(2.3)$ & 0 & $2(66.7)$ & $1(33.3)$ & 0.462 \\
\hline Normal & $64(49.2)$ & $8(12.5)$ & $14(21.9)$ & $42(65.6)$ & \\
\hline Overweight & $44(33.8)$ & $5(11.4)$ & $16(36.4)$ & $23(52.3)$ & \\
\hline Obese & $19(14.6)$ & $2(10.5)$ & $4(21.1)$ & $13(68.4)$ & \\
\hline \multicolumn{6}{|l|}{ Length of treatment } \\
\hline$<10$ Years & 110 & $14(14.6)$ & $25(26.0)$ & $57(59.4)$ & 0.180 \\
\hline$>10$ Years & 20 & $1(2.9)$ & $11(32.4)$ & $22(64.7)$ & \\
\hline \multicolumn{6}{|l|}{ Length of hypertension } \\
\hline$<10$ years & 110 & $14(14.6)$ & $25(26.0)$ & $57(59.4)$ & 0.180 \\
\hline$>10$ years & 20 & $1(2.9)$ & $11(32.4)$ & $22(64.7)$ & \\
\hline
\end{tabular}

without hypertension (Ghani et al., 2016). According to Perry and Potter (2010),the elderly usually experience an increase in systolic blood pressure associated with decreased elasticity of blood vessels and this increases the risk of diseases associated with hypertension. In addition, structural and functional changes in the peripheral vascular system are responsible for changes in blood pressure that occur in old age. These changes include atherosclerosis, loss of elasticity of the connective tissue, and reduction in relaxation of vascular smooth muscle.

Consequently, the aorta and large arteries are reduced in the ability to anocytate the volume of blood pumped by the heart (stroke volume), resulting in decreasing cardiac output and increasing peripheral resistance (Brunner \& Suddarth, 2002). Based on the above explanation, the researchers assume that hypertension increases the risk factors for cardiovascular disease. That is because the current pattern of human life which prefers to consume instant food or junk and fatty food, and has smoking habits increasingly makes the heart workload increase. So, if someone with hypertension needs to control blood pressure in order to reduce the risk of cardiovascular disease, she or he needs to adopt a healthier lifestyle.

Based on this study, it is known that the Body Mass Index in hypertensive patients shows more than half of respondents (68.4\%) have BMI obese status with high risk of CVD in the next 10 years. This can be explained as that the effect of obesity on coronary heart disease does not always stand alone, but is usually exacerbated by other factors. Previous study using Framingham Risk Score for lipid showed that for every $10 \%$ increase in body weight, systolic blood pressure rises by $6.5 \mathrm{mmHg}$, plasma cholesterol is
$12 \mathrm{mg} / \mathrm{dl}$ and blood glucose level is $2 \mathrm{mg} / \mathrm{dl}$ (Djafri, Monalisa, Elytha, \& Machmud, 2017). This is supported by Jneid and Thacker (2001) who proved a significant relationship between obesity and coronary heart disease with a pooled RR of 1.81 (95\% CI 1.56-2.10). There is a significant relationship between obesity and coronary heart disease because obesity can increase blood pressure, triglyceride levels, cholesterol, glucose resistance, and blood clotting. Increased blood pressure makes blood vessels vulnerable to thickening and narrowing. If this occurs in the coronary arteries, it will cause coronary heart disease.

Duration of HTN and duration of HTN treatment show that more than half $(64.7 \%)$ or $>10$ years of respondents are at high risk of CVD in the next 10 years. This is supported by Novriyanti and Usnizar (2014) that hypertension duration shows risk factors for CHD with 11-15 years hypertension category dominating by $47.9 \%$. This shows that the longer the hypertension, the higher the risk of CHD. Increased blood pressure over a long period of time will result in structural changes in blood vessels. These include changes in macro and microvascular structure. Changes in macrovascular arteries become stiff and changes in amplification are central to peripheral pressure. Microvascular changes are in the form of changes in the ratio of blood vessels and lumen in large arterioles, vasomotor tone abnormalities and 'structural rarefaction' meaning loss of microvascular blood flow does not flow to all microvascular to maintain perfusion to certain capillaries. Changes in structure will interfere with tissue perfusion, so that, in the long term, hypertension can result in damage to body organs. 
This causes myocardial infarction, stroke, heart failure, and kidney failure (Hall et al., 2015; Neter et al., 2003: :Yannoutsos et al., 2014).

In this research, limitations are that measurement of blood pressure was not carried out twice, difficulty to get respondents and the short time in the selection of respondents.

\section{CONCLUSION}

Prevalence of the estimated risk of CVD in the next 10 years in hypertensive patients results in a high category (60.8\%). Differences in demographic data in hypertensive patients showed men are at high risk of developing CVD in the next 10 years compared to women with an average age of 61.3 years. Furthermore, hypertension with an average of $142.2 \mathrm{mmHg}$ showed high risk of CVD in the next 10 years. For BMI status, obese status estimation was with high category. Duration of hypertension and length of treatment of high-risk hypertension CVD in the next 10 years have significant differences. It is expected that hospitals can pay attention to patients with obesity to obtain treatments or education related to obesity about prevention of heart disease in the next 10 years. Future research can be done, such as the factors that influence the risk of CVD in hypertensive patients.

\section{REFERENCES}

Agostino, R. B. D., Vasan, R. S., Pencina, M. J., Philip, A., Cobain, M., Massaro, J. M., \& Kannel, W. B. (2008). General Cardiovascular Risk Profile for Use in Primary Care. Journal of The American Heart Association. https://doi.org/10.1161/CIRCULATIONAHA.107. 699579

AHA. (2019). Atherosclerosis. Retrieved May 27, 2020, from https://www.heart.org/en/healthtopics/cholesterol/aboutcholesterol/atherosclerosis

Anwar, T. (2004). Angina Pektoris Tak Stabil (Universitas Sumatra Utara). Retrieved from https://www.researchgate.net/publication/4232 1445_Angina_Pektoris_Tak_Stabil

Arnett, D. K., Blumenthal, R. S., Albert, M. A., Buroker, A. B., Goldberger, Z. D., Hahn, E. J., ... Ziaeian, B. (2019). 2019 ACC/AHA Guideline on the Primary Prevention of Cardiovascular Disease: A Report of the American College of Cardiology/American Heart Association Task Force on Clinical Practice Guidelines. Circulation, 140(11), e596-e646. https://doi.org/10.1161/CIR.000000000000067 8

Badan Penelitian dan Pengembangan Kesehatan. (2018). HASIL UTAMA RISKESDAS 2018. Retrieved from

https://www.kemkes.go.id/resources/download /info-terkini/hasil-riskesdas-2018.pdf

Bell, N. R., Singh, H., Grad, R., Moore, E. A., Dickinson, J. A., Kasperavicius, D., \& Kretschmer, K. L. (2017).
Prevention in Practice. Canadian Family Physician, 63, 521-524.

Brunner, S., \& Suddarth, D. (2002). Buku ajar keperawatan medikal bedah. EGC, Jakarta.

Budiman; Sihombing, Rosmariana;Pradina, P. (2015). Hubungan dislipidemia, hipertensi dan diabetes melitus dengan kejadian infark miokard akut. Jurnal Kesehatan Masyarakat Andalas, 32-37.

Cohen, J. (1992). Quantitative Methods In Psychology. 112(1), 155-159.

Dhungana, R. R., Thapa, P., Devkota, S., Banik, P. C., Gurung, Y., Mumu, S. J., ... Ali, L. (2018). Prevalence of cardiovascular disease risk factors: A community-based cross-sectional study in a periurban community of Kathmandu, Nepal. Indian Heart Journal, 70, S20-S27. https://doi.org/10.1016/j.ihj.2018.03.003

Djafri, D., Monalisa, Elytha, F., \& Machmud, R. (2017). Efek modifikasi faktor risiko modifiable penyakit jantung koroner: a hospital-based matched case control study. Jurnal Kesehatan Masyarakat Andalas, 11(94), 93-99.

Emor, Engelin; Panda, Agnes; Pangemanan, J. (2017). Prediksi Tingkat Risiko Penyakit Kardiovaskuler Aterosklerotik pada Pasien yang Berobat di Poliklinik Penyakit Dalam RSUP Prof . Dr . R . D . Kandou Manado. Jurnal E-Clinic (ECI), 5(2). https://doi.org/https://doi.org/10.35790/ecl.5.2 .2017.18284

Endah, R., Patriyani, H., \& Purwanto, D. F. (2016). Faktor Dominan Risiko Terjadinya Penyakit Jantung Koroner (PJK). Jurnal Keperawatan Global, 1, 23-30.

Frostegård, J. (2013, May 1). Immunity, atherosclerosis and cardiovascular disease. BMC Medicine, Vol. 11, p. 117. https://doi.org/10.1186/1741-7015-11-117

Ghani, L., Dewi, M., \& Novriani, H. (2016). Faktor Risiko Dominan Penyakit Jantung Koroner di Indonesia. Buletin Penelitian Kesehatan, 44(3), 153-164.

Hall, J. E., Carmo, J. M., Silva, A. A., Wang, Z., \& Hall, M. E. (2015). Obesity-Induced Hypertension Interaction of Neurohumoral and Renal Mechanisms John. Circulation Research, 9911007. https://doi.org/10.1161/CIRCRESAHA.116.3056 97

Hassan, K., Mohydin, B., Fawwad, A., Waris, N., Iqbal, S., \& Jawaid, M. (2018). Predicting the risk of atherosclerotic cardiovascular disease ( ASCVD ) in Pakistani population. Clinical Epidemiology and Global Health, (February), 0-1. https://doi.org/10.1016/j.cegh.2018.04.002

Jneid, H \& Thacker, H. L. (2001). Coronary artery disease in women : Different, often undertreated. CLEVELAND CLINIC JOURNAL OF MEDICINE, 68(5), 441-448.

Kemenkes RI. (2014). Infodatin: Situasi Kesehatan Jantung. Jakarta: Pusat Data dan Informasi Kementerian Kesehatan RI. 
Lloyd-Jones, D. M., Braun, L. T., Ndumele, C., Smith, S., Sperling, L., Virani, S., \& Blumenthal, R. (2019). Use of Risk Assessment Tools to Guide Decision-Making in the Primary Prevention of Atherosclerotic Cardiovascular Disease. 73(24). https://doi.org/10.1016/j.jacc.2018.11.005

Marleni, L., \& Alhabib, A. (2017). Faktor Risiko Penyakit Jantung Koroner di RSI SITI Khadijah Palembang. Jurnal Kesehatan, VIII(3), 478-483.

Marrugat, J., Subirana, I., Comı, E., Cabezas, C., Vila, J., Elosua, R., ... Gene, J. (2007). Validity of an adaptation of the Framingham cardiovascular risk function: the VERIFICA study. J Epidemiol Community Health, 61, 40-47. https://doi.org/10.1136/jech.2005.038505

Marso, S. P., McGuire, D. K., Zinman, B., Poulter, N. R., Emerson, S. S., Pieber, T. R., ... Buse, J. B. (2016). Design of DEVOTE (Trial Comparing Cardiovascular Safety of Insulin Degludec vs Insulin Glargine in Patients With Type 2 Diabetes at High Risk of Cardiovascular Events) - DEVOTE 1. American Heart Journal, 179, 175-183. https://doi.org/10.1016/j.ahj.2016.06.004

Neter, J. E., Stam, B. E., Kok, F. J., Grobbee, D. E., \& Geleijnse, J. M. (2003). Influence of Weight Reduction on Blood Pressure A Meta-Analysis of Randomized Controlled Trials. 878-884. https://doi.org/10.1161/01.HYP.0000094221.86 888.AE

Novriyanti, I. D., \& Usnizar, F. (2014). Pengaruh Lama Hipertensi Terhadap Penyakit Jantung Koroner di Poliklinik Kardiologi RSUP. Dr. Mohammad Hoesin Palembang 2012. 1(1), 55-60.

Nuraini, B. (2015). Risk factors of hypertension. Majority, 4(5), 10-19.

Perry, \& Potter. (2010). Potter \& Perry's Fundamentals of Nursing. Retrieved May 27, 2020, from https://books.google.co.id/books?id=VFnSC9HWZwC\&pg=PT3476\&lpg=PT3476\&dq=pe rry+potter+elderly+hypertension\&source=bl\&ots =relzeg65iS\&sig=ACfU3U0vWP0T30oDxLscQVP_ _bsaZIcMw\&hl=en\&sa=X\&ved=2ahUKEwiamaK1 39PpAhUSU30KHaxAB5sQ6AEwAnoECAoQAQ\#v =onepage $\& \mathrm{q}=$ perry pot

Sa'adeh, H. H., Darwazeh, R. N., Khalil, A. A., \& Zyoud, S. H. (2018). Knowledge, attitudes and practices of hypertensive patients towards prevention and early detection of chronic kidney disease : a cross sectional study from Palestine. Clinical Hypertension, 1-13. https://doi.org/https://doi.org/10.1186/s40885 -018-0091-7

West Java Health Office. (2016). Laporan Kinerja Instansi Pemerintah (LKIP) 2016 Dinas Kesehatan Jawa Barat. Jawa barat.

Whelton, P. K., Carey, R. M., Aronow, W. S., Casey, D. E., Collins, K. J., Himmelfarb, C. D., ... Gentile, F. (2018). Clinical Practice Guideline 2017 ACC / AHA / AAPA / ABC / ACPM / AGS / APhA / ASH / ASPC / NMA / PCNA Guideline for the Prevention, Detection, Evaluation, and Management of High Blood Pressure in Adults A Report of the American College of Cardiology https://doi.org/10.1161/HYP.00000000000000 65

WHO. (2019). Ethics and health: templates for imformed consent forms.

Yannoutsos, A., Levy, B. I., Safar, M. E., Slama, G., \& Blacher, J. (2014). Pathophysiology ofhypertension: interactions between macro andmicrovascular alterations through endothelial dysfunction. Jhypertension, 32(2), 216-224. https://doi.org/10.1097/HJH.000000000000002 1

Yonata, A., Satria, A., \& Pratama, P. (2016). Hipertensi sebagai Faktor Pencetus Terjadinya Stroke. Majority, 5(September 2016), 17-21. 